\title{
Why Education Matters: Reflections on the last 50 years
}

Entering the new year of 2018, made me realise that I am celebrating 50 years in the profession, most of which have been spent in nurse education. Nursing and its education have seen changes that could not have been imagined when I started nursing. With no dedicated nursing degree in the UK at the time I qualified, it was less than 20 years later, when nurse education moved wholesale, from schools of nursing into higher education with the project 2000 diploma and almost a further 25 years until it became all graduate entry from September 2013 (RCN 2012). So, in my own career, the profession has moved from an all-training route to registration to an all-degree route, with many universities requiring doctoral preparation to teach.

In my early career, the evidence based practice (EBP) movement had not been invented. It arose initially from McMasters University in Canada in the 1980s and, from its origins in evidence-based medicine, quickly took hold in nursing in the late 1990s (Sacket et al 1996).

So, how did the move into higher education change the profession? For the students, it changed their whole preparation towards registration. From the previous $9.00-17.00$ teaching day, and $80 \%$ of their programme in practice, the students gained space within the curriculum for self-study. This self-study aims to support students to search the literature, prepare for seminar work and develop their independent learning. They were no longer passive recipients of education delivery but partners in the process. As Ingrams (2016) attests, those countries where graduate nursing is more established, the value of degree studies became visible, with clinical managers recognising them as knowledgeable doers and within one year of qualifying, were way ahead of their non-graduate peers in relation to patient safety, their knowledge about medicines and they were perceived as critical thinkers who were proactive in detecting and managing the deteriorating patient. Additionally, the work of Aiken (2014) in her large European study acknowledges that each 10\% increase in the proportion of degree level nurses in hospitals is associated with a $7 \%$ decrease in patient mortality. At the same time, nurse educators were not only studying themselves, but they began to research and establish a body of evidence to support what nurses were doing.

Alongside this, even prior to the NHS Plan (2000), service began to change. New roles emerged with investment in the senior clinical leadership and the introduction of the Consultant nurse role (DH 1999). Graduate study became the education level for appointments to nurse consultant role and, since 2010 (DH 2010) they now require a minimum of masters degree education, with some completing doctoral study.

I learned a convoluted way to understand the importance of education for practice. After training as a general nurse and then as a midwife, I travelled to the tropical coast of Colombia, South America to work in a 30-bedded bush hospital, as a volunteer. There was no internet, very few outdated textbooks and no real connection with the outside world apart from the radio. Suddenly education became important. Without medical aid, it was difficult to know if, what we were doing to treat regular tropical diseases was based on best evidence. After 6 years in the tropics, with the final year leading the operating department and emergency room, in a private hospital in the city, I realised just how much I needed to know. Although I led the departments, I quickly recognised that I was not a thought leader, a leader who knew the business of this speciality, and my team knew this too. I became hungry to learn and after a year learning what I could, I decided to move back to London to learn all 
about theatre nursing, so that I could return to run the department based on the best evidence. However, after one year in London, I was captivated by learning and realised that after continuous questioning of my superiors, the only reliable way to approach evidence based practice, was to find out for myself. I appreciate now, that you do not need to travel to the other side of the world to learn the importance of education for practice and that as a teacher, my role is to create in the minds of students, an excitement and a hunger for learning so that they too, will recognise the importance of lifelong learning and its significance in whatever area of practice they decide to follow. Lifelong learning is not about simply gaining more qualifications. It is much more than that. It is about having that inner appetite to continue to learn and enhance your practice underpinned by the best available evidence.

My message is very definitely that education does matter. We never stop learning and I would encourage all nurses to make the most of your opportunities and to keep reading and learning to improve your patient care. As professionals, that is our obligation.

Words: 817

References:

Aiken, L.H., Sloane, D.M., Bruyneel, L., Van den Heede, K., Griffiths, P., Busse, R., Diomidous, M.. Kinnunen, J., Kozka M. Lesaffre, E.., McHugh, M.D., Moreno-Casbas, M.T., Rafferty, A.M., Schwendimann, R., Scott, P.A., Tishelman, C., van Achterberg, T. and Sermeus, W. (2014) Nurse staffing and education and hospital mortality in nine European countries: a retrospective observational study. The Lancet, February 26. Accessed at http://dx.doi.org/10.1016/S0140-6736(13)62631-8 on 28.01.3018.

Department of Health (DH) (1999) Nurse, midwife and health visitor consultants: establishing posts and making appointments. Health Service Circular HSC 1999/217. 29 September Leeds: NHSE

Department of Health (2000) The NHS Plan. A plan for investment, A plan for reform. Her Majesty's Stationery Office, London.

Department of Health (2010) Advanced level nursing: a position statement. Accessed at: https://www.gov.uk/government/publications/advanced-level-nursing-a-position-statement on 28.1 .18

Ingrams, P. (2016) Graduate-level entry to nursing: international perspectives. British Journal of Nursing, 25(10), 560 - 561.

Sackett, DL, Rosenberg, WM, Gray, JA, Haynes, R.B. and Scott Richardson, W. (1996)

Evidence based medicine: what it is and what it isn't. British Medical Journal, 312: 71.

Accessed at: http://www.bmi.com/content/312/7023/71 on 27.1.18.

Royal College of Nursing (2012) Quality with Compassion: the future of nursing education Report of the Willis Commission on Nursing. Royal College of Nursing, London.

Professor Elizabeth Rosser

Bournemouth University

28.1.18 